\title{
Perancangan Fasilitas Kerja untuk Mereduksi Human Error
}

\author{
Harmein Nasution ${ }^{1 *}$, Nazlina ${ }^{1}$
}

\begin{abstract}
Work equipments and environment which are not design ergonomically can cause physical exhaustion to the workers. As a result of that physical exhaustion, many defects in the production lines can happen due to human error and also cause musculoskeletal complaints. To overcome, those effects, we occupied methods for analyzing the workers posture based on the SNQ (Standard Nordic Questionnaire), plibel, QEC (Quick Exposure Check) and biomechanism. Moreover, we applied those methods for designing rolling machines and grip egrek ergonomically, so that the defects on those production lines can be minimized.
\end{abstract}

Keywords:Muskuloskeletal disorder, QEC, biomechanism, human error.

\section{Pendahuluan}

Menurut Dhillon [3] human error didefinisikan sebagai kegagalan menyelesaikan pekerjaan yang dapat menimbulkan gangguan terhadap jadwal operasi atau mengakibatkan kerusakan peralatan. Sedangkan menurut Meister [8], human error dapat diklasifikasikan ke dalam beberapa kategori yaitu salah satunya error pada proses perancangan. Error jenis ini disebabkan oleh hasil rancangan yang kurang sesuai dengan sistem kerja. Hal ini merupakan kegagalan untuk mengimplementasikan kebutuhan manusia dalam rancangan dan kegagalan untuk memperhitungkan efektivitas interaksi antara manusia dan mesin. Akibat desain dan lingkungan kerja yang tidak ergonomiks akan mempercepat kelelahan fisik, yang pada akhirnya akan menimbulkan human error dalam menghasilkan produk (Susetyoet al.[13])

Dampak terjadinya human error ditunjukkan melalui adanya produk cacat yang dihasilkan dalam berproduksi. PT Sarana Panen Perkasa merupakan perusahaan yang bergerak di bidang proses produksi alat-alat perkebunan kelapa sawit seperti egrek, dodos, kampak, parang, dan gancu. Berdasarkan data perusahaan, egrek merupakan produk yang jumlah permintaannya sangat tinggi yaitu 5000 pcs/bulan, artinya jumlah produk yang dihasilkan mencapai 200 pcs/hari. Perusahaan harus menjamin produk tetap berkualitas meskipun jumlah permintaan tinggi. Hasil evaluasi selama penelitian berlangsung jumlah produk cacat mencapai 10\% dari keseluruhan produksi. Cacat produk ini biasanya disebabkan oleh faktor kelelahan, contoh kasus penurunan produksi dan jumlah yang cacat berdasarkan jam kerja, dapat dilihat pada Tabel 1 .

\footnotetext{
1 Fakultas Teknik, Departemen Teknik Industri, Universitas Sumatra Utara. Л. Almamater 1, Kampus USU, Medan 20155 , Indonesia.Email: hamein_nasution@yahoo.com

*Penulis korespondensi
}

Tabel 1. Jumlah produk per hari

\begin{tabular}{|c|c|c|c|c|}
\hline No & Jam kerja & $\begin{array}{l}\text { Jumlah produk } \\
\text { sesuai standar }\end{array}$ & $\begin{array}{c}\text { Jumlah } \\
\text { produk cacat }\end{array}$ & Total \\
\hline 1 & $\begin{array}{c}08.00 \mathrm{~s} / \mathrm{d} \\
10.00 \mathrm{WIB}\end{array}$ & 45 & - & 45 \\
\hline 2 & $\begin{array}{c}10.30 \mathrm{~s} / \mathrm{d} \\
12.00 \mathrm{WIB}\end{array}$ & 38 & 2 & 40 \\
\hline 3 & $\begin{array}{c}13.00 \mathrm{~s} / \mathrm{d} \\
15.00 \mathrm{WIB}\end{array}$ & 32 & 4 & 36 \\
\hline 4 & $\begin{array}{c}15.30 \mathrm{~s} / \mathrm{d} \\
17.00 \mathrm{WIB}\end{array}$ & 28 & 5 & 33 \\
\hline
\end{tabular}

Sumber: PT. Sarana Panen Perkasa

Peningkatan produk cacat ini dikarenakan adanya faktor kelelahan secara kontinu terhadap pekerja. Timbulnya kelelahan pada pekerja disebabkan oleh keluhan musculoskeletal akibat dari pembebanan target produksi yang harus dicapai pekerja. Kegiatan yang repetitif dengan pengeluaran tenaga yang besar dan postur kerja yang tidak ergonomis merupakan penyebab terjadinya keluhan musculoskeletal. Kegiatan repetitif yang dilakukan pada proses produksi egrek dimulai dari proses tarik ekor, buka bagian depan, pemotongan, hammering, formatting, flatting, grinding, treatment, dan finishing. Seluruh proses produksi menggunakan mesin manual seperti mesin rolling, mesin hammer, mesin format, dan mesin gerinda sehingga output yang dihasilkan tergantung pada usaha atau tenaga manusia. Berdasarkan hasil pengamatan pada lantai produksi, stasiun kerja hammering merupakan stasiun kerja yang beban kerjanya paling berat karena pada stasiun ini terjadi proses pembengkokkan yang membutuhkan tenaga yang cukup besar. Estimasi besar gaya otot yang dikeluarkan sebesar $4170 \mathrm{~N}$. Estimasi besar gaya tersebut dijelaskan pada bagian metodologi penelitian.

Proses pembengkokkan dalam stasiun kerja hammering yang mengeluarkan tenaga cukup besar menggunakan fasilitas kerja berupa mesin rolling. Mesin rolling yang digunakan memiliki beberapa kekurangan yaitu,tidak sesuai dengan metode kerja, 
ukuran tinggi mesin yang terlalu rendah, dan tidak sesuai dengan dimensi antropometri pekerja. Hal ini menimbulkan keluhan terhadap pekerja yang diidentifikasi berdasarkan SNQ (Standard Nordic Questionnaire) dan plibel sehingga diketahui keluhan musculoskeletal yang dialami pekerja. Bahwa prevalensi gangguan musculoskeletal pada pekerja dapat dideteksi dengan melakukan survei menggunakan kuesioner SNQ (Aghili et al.[1]). Dari hasil pengamatan, keluhan musculoskeletal terjadi pada bagian tubuh pergelangan tangan, bahu, dan genggaman tangan dikarenakan aktivitas yang repetitif dan otot terus-menerus berkontraksi. Rasa sakit pada genggaman tangan terutama disebabkan oleh cara memegang egrek pada proses pembentukan ujung egrek. Hasil penilaian postur kerja dengan metode QEC (Quick Exposure Check) pada proses pembengkokkan dengan menarik tuas mesin rolling menunjukkan suatu tindakan yang memerlukan perbaikan postur kerja. Perbaikan postur kerja dapat dimulai dari penyesuaian mesin rolling dengan metode kerja, penyesuaian dimensi alat dengan metode kerja, dan penyesuaian mesin rolling dengan antropometri pekerja. Hal tersebut dapat meminimalkan keluhan musculoskeletal terhadap operator. Sesuai dengan pernyataan Humantech [6] bahwa keluhan musculoskeletal akan mengakibatkan produktivitas menurun dan menurut Pheasant [10], Hendra dan Suwandi[5], musculoskeletal juga berpengaruh terhadap bertambahnya produk cacat.

Penentuan human error pada proses pembengkokan menggunakan pendekatan HRA (human reliabilitiy assessment). Adapun metode penilaian yang digunakan pada pendekatan HRA yaitu metode FTA (fault tree analysis), HEART (human error assessment and reduction technique), dan HTA (hierarchical task analysis). Berdasarkan hasil pengamatan dan wawancara langsung selama 2 minggu dengan jumlah sampel 2500 produk dengan menggunakan SNQ dan Plibel, maka dapat diuraikan faktor-faktor yang mempengaruhi tingkat kegagalan operator dalam proses pembengkokkan yang disebut error producing conditions (EPCs), yaitu, tidak ada prosedur yang jelas untuk memperbaiki kesalahan, kurangnya kegiatan pemeriksaan, dan peralatan tidak efektif. Nilai human error probabilitiy (HEP) berdasarkan fault tree analysis (FTA) adalah 0,5978. Peningkatan nilai Human error probabilitiy (HEP) ini berbanding lurus dengan jumlah produk cacat yang dihasilkan, sehingga dapat mengakibatkan terganggunya kelancaran proses produksi. Hal ini sesuai dengan hasil penelitian yang dilakukan oleh Reinachet al. [11] pada remote control locomotive operations dan Akash, et al. [2] pada computer aided design. Untuk meminimalkan produk yang cacat dapat dilakukan suatu perbaikan fasilitas kerja dengan mengurangi probabilitas human error (Fabio, et al.[4]; Lyons, et al.[7]).
Tujuan dilakukan penelitian ini adalah untuk merancang fasilitas kerja (mesin rolling dan pegangan egrek) yang ergonomis untuk mereduksi human error pada proses pembengkokkan di stasiun hammering sehingga dapat meminimalkan produk yang cacat.

\section{Metode Penelitian}

Adapun hipotesa penyelesaian masalah yaitu dengan mereduksi tingkat probabilitas human error (HEP) dari keluhan muskuloskeletal, diharapkan dapat mengurangi produk cacat. Mereduksi human error pada proses pembengkokkan di stasiun hammering dapat dilakukan dengan cara merancang fasilitas kerja (mesin rolling dan pegangan egrek) yang ergonomis. Langkah pertama adalah melakukan wawancara terhadap pekerja tentang uraian kegiatan pada proses pembengkokkan di stasiun hammering. Jumlah operator yang bekerja pada proses pembengkokkan di stasiun hammering adalah 3 orang. Kemudian dilakukan penyebaran kuisioner SNQ dan Plibel kepada ketiga operator untuk mengetahui keluhan musculoskeletal yang dialami. Penilaian pembobotan kuisioner SNQ dikategorikan sebagai berikut: tidak sakit (bobot 0), agak sakit (bobot 1), sakit (bobot 2), dan sangat sakit (bobot 3). Plibelmemeriksa penyebab utama resiko musculoskeletal serta hubungannya dengan penilaian tempat kerja dengan menggunakan alat checklist sederhana yang disebarkan kepada ketiga operator. Berdasarkan kuesioner SNQ dan Plibel diketahui bahwa keluhan yang sering terjadi terdapat pada bagian tubuh leher, bahu, punggung bagian atas, siku, lengan, tangan, kaki, paha, dan lutut.

Langkah selanjutnya melakukan penilaian postur kerja terhadap salah satu operator dengan menggunakan metode QEC. Operator pertama, sudah bekerja pada proses pembengkokan selama 3 tahun sejak perusahaan didirikan. Operator kedua, bekerja selama 1 tahun tetapi hanya pada saat jam lembur saja karena dibutuhkan tenaga tambahan untuk mencapai target. Operator ketiga masih bekerja selama 2 bulan, jadi masih tahap pembelajaran dan belum mahir. Oleh karena itu, berdasarkan hasil pengamatan, operator 1 dipilih sebagai pekerja normal dan dijadikan sebagai objek penelitian.

Tabel 2. Kriteria tindakan

\begin{tabular}{ccl}
\hline Tindakan & $\begin{array}{c}\text { Persentase } \\
\text { skor (E) }\end{array}$ & Tindakan \\
\hline 1 & $0-40 \%$ & Aman \\
2 & $41-50 \%$ & $\begin{array}{l}\text { Diperlukan beberapa waktu ke } \\
\text { depan }\end{array}$ \\
3 & $51-70 \%$ & Tindakan dalam waktu dekat \\
4 & $71-100 \%$ & Tindakan sekarang juga \\
\hline
\end{tabular}

Stanton [12]. 
Penilaian postur kerja dengan metode QEC dilakukan dari dua sisi. Penilaian pertama didasarkan kepada penilaian pengamat (Observer's Assesment) dengan mengisi Observer's Assessment Checklist dan penilaian kedua didasarkan kepada penilaian pekerja (Worker's Assessment) dengan mengisi Worker's Assessment Checklist. Selanjutnya dengan penjumlahan setiap skor hasil kombinasi masing-masing bagian, diperoleh skor dengan kategori level tindakan.

$E(\%)=\frac{X}{X_{\text {maks }}} 100 \%$

dimana

$X \quad$ : total skor yang diperoleh dari penilaian terhadap postur

$X_{\text {maks }}$ : Total skor maksimum untuk postur kerja

Adapun penilaian postur kerja dengan metode QEC pada proses pembengkokkan yaitu: (1) Penilaian elemen kerja dengan kriteria aman yaitu membawa carbon steel ke tempat pembengkokkan sebesar $39,77 \%$. (2) Penilaian elemen kerja dengan kriteria diperlukan perbaikan untuk beberapa waktu ke depan, yaitu pada elemen kerja: meletakkan carbon steel pada tungku pemanasan $45,67 \%$, memanaskan carbon steel 50\%, mengambil carbon steel yang sudah dipanaskan 48,14\%, carbon steel dicelupkan ke dalam air setelah proses pemanasan 40,74\%, meletakkan carbon steel pada mesin rolling $45,67 \%$, proses pemeriksaan $46,91 \%$ dan proses pukul rata 44,44\%. (3) Penilaian elemen kerja dengan dengan kriteria tindakan dalam waktu dekat yaitu pada proses pembengkokkan dengan menarik tuas mesin rolling sebesar $58,52 \%$.

Selanjutnya dilakukan penilaian biomekanika dengan perhitungan estimasi besar gaya otot yang dikeluarkan pekerja terhadap segmen tubuh yang mengalami keluhan berdasarkan hasil identifikasi dari kuesioner SNQ dan Plibel. Dari hasil penilaian biomekanika yang paling besar terjadi proses pembengkokkan yang membutuhkan tenaga yang cukup besar. Estimasi besar gaya otot yang dikeluarkan sebesar 4170 N. Perhitungan di bawah ini menggunakan $W_{\text {badan }}=67 \mathrm{~kg}=656,6 \mathrm{~N} ; \quad \theta=30^{\circ}$; $W_{0}=10,6 \mathrm{~kg}=103,88 \mathrm{~N} ; \sum F_{y}=0 ; \sum F_{x}=0 ; \sum M=0$

\section{Notasi}

E $\quad$ : panjang lengan momen otot spinal erector dari L5/S1, dengan estimasi 0,05 m

$D \quad$ : jarak dari gaya perut ke L5/S1 dengan jarak 0,11 m (Nurmianto [9])

$\mathrm{M}_{\left(\frac{\mathrm{L} 5}{\mathrm{~S} 1}\right)} / \mathrm{M}_{\mathrm{t}}:$ momen resultan pada $\mathrm{L} 5 / \mathrm{S} 1$

$F_{A} \quad$ : gaya perut (Newton)

$P_{A} \quad$ : tekanan perut

$\theta_{H} \quad$ : sudut inklinasi perut

$\theta_{T} \quad$ : sudut inklinasi kaki

$\begin{array}{ll}A_{A} & : \text { luas diagragma }\left(465 \mathrm{~cm}^{2}\right) \\ W_{t o t} & : \text { gaya keseluruhan yang terjadi } \\ W_{o} & : \text { berat beban } \\ W_{H} & : \text { berat tangan } \\ W_{L A} & : \text { berat lengan bawah } \\ W_{U A} & : \text { berat lengan atas } \\ W_{T} & : \text { berat punggung } \\ F C & : \text { gaya kompresi pada L5/S1 }\end{array}$

Adapun perhitungan selengkapnya adalah sebagai berikut:

Gaya otot pada spinalerector:

a. Segmen telapak tangan

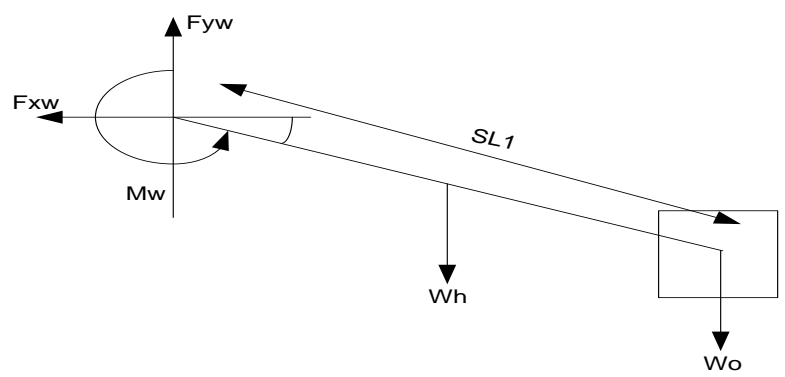

$S_{L 1}=0,17 \mathrm{~m}$

$W_{H}=0,6 \% W_{\text {badan }}=3,9396 N$

$M_{w}=\left(0,5 W_{H}+W_{0}\right) S_{L 1} \cos \theta$

$=15,584 \mathrm{Nm}$

b. Lengan bawah

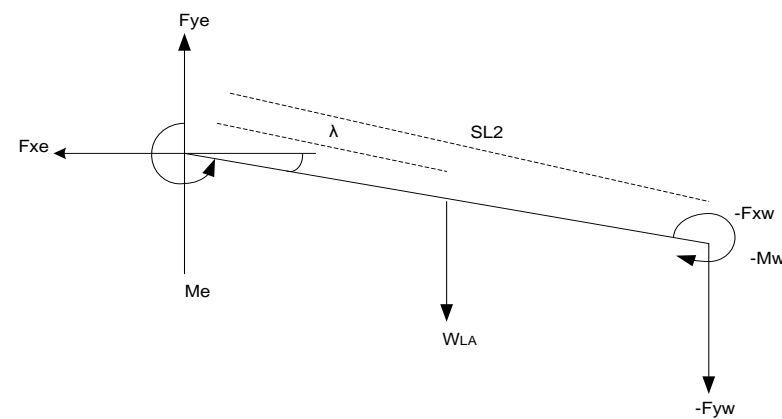

$S_{L 2}=0,26 \mathrm{~m} ; \lambda_{2}=43 \%$

$W_{L A}=1,7 \% W_{\text {badan }}=11,16 \mathrm{~N}$

$F_{y e}=F_{y w}+W_{L A}=118,89 \mathrm{~N}$

$M_{e}=M_{w}+\left(W_{L A} \lambda_{2} S_{L 2} \cos \theta\right)+\left(F_{y w} S_{L 2} \cos \theta\right)$ $=40,14 \mathrm{Nm}$

c. Lengan atas

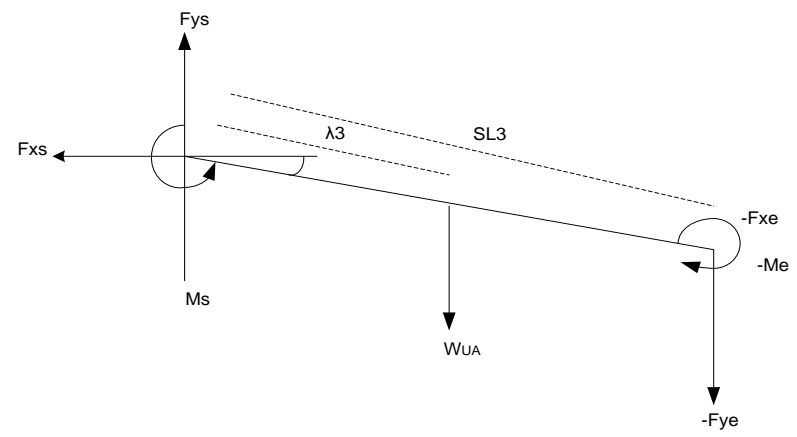




$$
\begin{aligned}
S_{L 3} & =0,24 \mathrm{~m} ; \lambda_{3}=43,6 \% ; \theta_{3}=40^{0} \\
W_{U A} & =2,8 \% W_{\text {badan }}=18,385 N \\
F_{y s} & =F_{y w}+W_{U A}=137,365 N \\
M_{s} & =M_{w}+\left(W_{U A} \lambda_{3} S_{L 3} \cos \theta_{3}\right)+\left(F_{y e} S_{L 3} \cos \theta_{3}\right) \\
& =62,37 \mathrm{Nm}
\end{aligned}
$$

d. Punggung

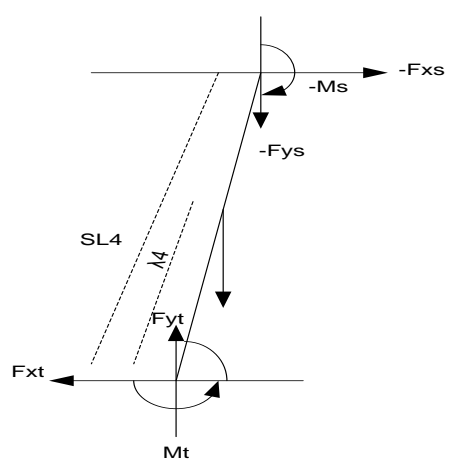

$S_{L 4}=0,56 \mathrm{~m} ; \lambda_{4}=67 \% ; \theta_{4}=70^{0}$

$W_{T}=50 \% W_{\text {badan }}=328,3 \mathrm{~N}$

$F_{y t}=2 F_{y s}+W_{T}=603,03 N$

$M_{t}=2 M_{s}+\left(W_{T} \lambda_{4} S_{L 4} \cos \theta_{4}\right)+\left(2 F_{y S} S_{L 4} \cos \theta_{4}\right)$

$$
=202,01 \mathrm{Nm}
$$

$P_{A}=\frac{1}{75}\left(10^{-4}\left[43-0,36\left(\theta_{H}+\theta_{T}\right)\right]\left(\frac{M_{L 5}}{S_{1}}\right)^{1,8}\right)$

$$
=0,0038
$$

$F_{A}=P_{A} \times A_{A}=0,0038 \times 465 \mathrm{~cm}^{2}=1,7502 \mathrm{~cm}^{2}$

$F_{m} \times E=\frac{M_{L 5}}{S_{1}}-F_{A} D$ maka $F_{m}=4036 N$

$$
W_{\text {tot }}=W_{0}+2 W_{H}+2 W_{L A}+2 W_{U A}+W_{t}
$$

$$
=393,27 \mathrm{~N}
$$

$F_{c}=W_{\text {tot }} \cos \theta_{4}-F_{A}+F_{m}=4170,51 N$

Diperolah $A L<F_{c}<M P L(3500<4170,51<6500)$ di mana AL dan MPL adalah ketetapan, maka gaya angkat dikategorikan perlu hati-hati.
Langkah yang dilakukan kemudian adalah penentuan probabilitas human error menggunakan pendekatan HRA yaitu metode HTA (hierarchical task analysis), HEART (human error assessment and reduction technique) dan FTA (fault tree analysis). Langkah pertama untuk menentukan probabilitas human error adalah dengan menggambarkan seluruh item pekerjaan ke dalam bentuk hirarki. Untuk proses pembengkokkan dapat dilihat pada Gambar 1. Dengan menggunakan metode HTA, pekerjaan yang dianalisis menjadi lebih rinci dan sistematis karena pengelompokan tersebut digam-

\begin{tabular}{|c|c|c|c|c|}
\hline $\begin{array}{l}\text { Nomor } \\
\text { Urut } \\
\text { (Tabel } \\
\text { EPCs) }\end{array}$ & EPCs & $\begin{array}{l}\text { Max } \\
\text { Effect }\end{array}$ & APOE & $\begin{array}{c}\text { AE } \\
((\text { Max.Effect-1)x } \\
\text { APOE })+1)\end{array}$ \\
\hline 7 & $\begin{array}{l}\text { Tidak ada } \\
\text { prosedur } \\
\text { yang jelas } \\
\text { untuk } \\
\text { memperbaiki } \\
\text { kesalahan }\end{array}$ & 8 & 0,6 & $\begin{array}{c}((8-1) \times 0,6)+1)= \\
5,2\end{array}$ \\
\hline 17 & $\begin{array}{l}\text { Kurangnya } \\
\text { kegiatan } \\
\text { pemeriksaan }\end{array}$ & 3 & 0,4 & $\begin{array}{c}((3-1) \times 0,4)+1)= \\
1,8\end{array}$ \\
\hline 23 & $\begin{array}{l}\text { Peralatan } \\
\text { tidak andal }\end{array}$ & 1,6 & 0,6 & $\begin{array}{c}((1,6-1) \times 0,6)+1)= \\
1,36\end{array}$ \\
\hline
\end{tabular}
barkan ke dalam sebuah diagram pohon yang menunjukkan hirarki atau tingkatan setiap pekerjaan.

Berdasarkan hasil pengamatan dan wawancara langsung maka dapat diuraikan faktor-faktor EPCs yang mempengaruhi tingkat kegagalan operator dalam proses pembengkokkan dapat dilihat pada Tabel 3.

Tabel 3. Nilai proposi efek (APOE) dan perhitungan AE

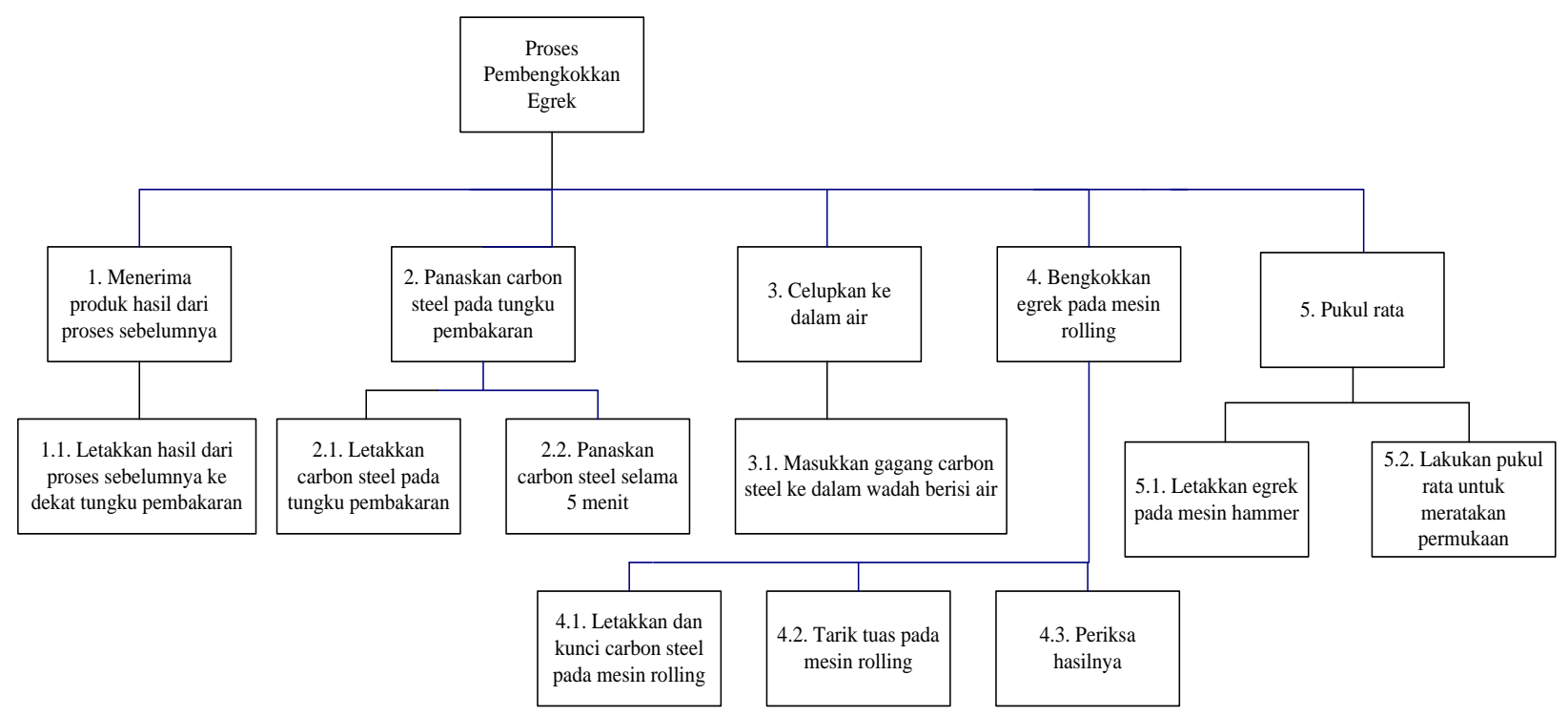

Gambar 1. Hierarchical task analysis (HTA) proses pembengkokkan 
Tabel 4. Nilai human error probability (HEP)

\begin{tabular}{ccccc}
\hline Kode & GTT & $\begin{array}{c}\text { Nominal human error } \\
\text { probability }\end{array}$ & Total AE & HEP \\
\hline 1.1. & $\mathrm{E}$ & 0,02 & 12,7296 & 0,2545 \\
2.1. & $\mathrm{G}$ & 0,0004 & 12,7296 & 0,0050 \\
2.2. & $\mathrm{G}$ & 0,0004 & 12,7296 & 0,0050 \\
3.1. & $\mathrm{E}$ & 0,02 & 12,7296 & 0,2545 \\
4.1. & $\mathrm{G}$ & 0,0004 & 12,7296 & 0,0050 \\
4.2. & $\mathrm{G}$ & 0,0004 & 12,7296 & 0,0050 \\
4.3. & $\mathrm{G}$ & 0,0004 & 12,7296 & 0,0050 \\
5.1. & $\mathrm{E}$ & 0,02 & 12,7296 & 0,2545 \\
5.2. & $\mathrm{G}$ & 0,0004 & 12,7296 & 0,0050 \\
\hline
\end{tabular}

Maka total probabilitas error berdasarkan Fault Tree Analysis adalah 0,5978

Tabel 5. Data dimensi antropometri pekerja

\begin{tabular}{ccrrrrrr}
\hline No & $\begin{array}{c}\text { PJ1 } \\
(\mathrm{cm})\end{array}$ & $\begin{array}{c}\text { PJ3 } \\
(\mathrm{cm})\end{array}$ & $\begin{array}{c}\text { PPT } \\
(\mathrm{cm})\end{array}$ & $\begin{array}{c}\text { LJ2345 } \\
(\mathrm{cm})\end{array}$ & $\begin{array}{c}\text { LT } \\
(\mathrm{cm})\end{array}$ & $\begin{array}{c}\text { JT } \\
(\mathrm{cm})\end{array}$ & $\begin{array}{c}\text { TSB } \\
(\mathrm{cm})\end{array}$ \\
\hline 1 & 7,2 & 10,3 & 9,7 & 8,5 & 9,3 & 75,5 & 108,4 \\
2 & 5,7 & 10,1 & 9,0 & 8,2 & 8,7 & 72,0 & 99,1 \\
3 & 7,6 & 10,8 & 11,0 & 7,5 & 9,4 & 78,0 & 102,2 \\
4 & 7,0 & 10,2 & 7,7 & 7,3 & 9,0 & 71,0 & 99,4 \\
5 & 6,3 & 9,8 & 7,2 & 7,0 & 8,2 & 71,0 & 94,5 \\
6 & 6,2 & 9,4 & 6,7 & 8,0 & 10,0 & 65,0 & 94,0 \\
7 & 6,5 & 10,2 & 7,2 & 7,7 & 9,4 & 67,0 & 98,5 \\
8 & 7,0 & 10,2 & 8,3 & 7,8 & 8,8 & 71,0 & 101,0 \\
9 & 6,6 & 10,3 & 10,2 & 8,0 & 9,3 & 71,0 & 99,0 \\
10 & 6,5 & 9,4 & 9,2 & 7,1 & 8,6 & 82,0 & 98,5 \\
11 & 6,8 & 10,8 & 9,7 & 7,3 & 9,3 & 73,0 & 98,7 \\
12 & 6,3 & 10,0 & 9,5 & 7,7 & 9,9 & 81,0 & 96,0 \\
13 & 7,7 & 10,3 & 9,8 & 8,0 & 10,2 & 75,0 & 115,0 \\
14 & 6,1 & 9,2 & 8,7 & 7,8 & 9,1 & 75,0 & 104,5 \\
15 & 6,8 & 11,1 & 9,4 & 8,1 & 9,3 & 74,0 & 100,3 \\
\hline
\end{tabular}

Nilai HEP untuk setiap kode pekerjaan dapat dilihat pada Tabel 4 .

Langkah terakhir adalah mereduksi human error dengan melakukan perancangan fasilitas kerja sesuai dengan antropometri pekerja. Dari penilaian SNQ dan plibel, terhadap operator terdapat bagian tubuh leher, bahu, punggung bagian atas, siku, lengan, tangan, kaki, paha, dan lutut.yang sering mengalami keluhan. Dengan mengurangi keluhan musculoskeletal pada bagian tubuh tersebut maka dapat mereduksi human error, sehingga perlu dilakukan perancangan fasilitas kerja yang menggunakan prinsip perancangan rata-rata (persentil 50). Antropometri yang dibutuhkan untuk modifykasi mesin rolling alat bantu pegangan egrek adalah tinggi siku berdiri (TSB), jangkauan tangan (JT), Lebar tangan (LT), Pangkal ke tangan + Panjang jari 3 (PPT + PJ3), Lebar jari $2345+$ Panjang jari 1, Pangkal ke tangan + Panjang jari 3 (PPT + PJ3), dan Lebar jari 1.

\section{Hasil dan Pembahasan}

Dari hasil pengumpulan dan pengolahan data yang dilakukan maka diperoleh hasil perancangan fasilitas kerja yang dapat dilihat pada Gambar 3.
Kekurangan pada mesin rolling aktual yaitu: dimensi tinggi mesin rolling yang tidak sesuai dengan antropometri operator mengakibatkan terjadinya keluhan musculoskeletal karena operator harus bekerja dengan posisi membungkuk, diameter handle terlalu kecil dan terbuat dari besi sehingga bagian tangan terasa sakit dan kasar, dan posisi holding hole berada pada bagian atas mesin sehingga percikan api pada saat proses pembengkokkan mengenai operator dan ketebalan holding hole untuk proses pembengkokkan tidak sesuai dengan ketebalan egrek dimana ketebalan egrek adalah 4 $\mathrm{mm}$. Untuk meminimalisasi human error dirancang suatu fasilitas kerja yang ergonomis.

Tabel 6. Spesifikasi rolling aktual

\begin{tabular}{ll}
\hline Mesin rolling aktual & \\
\hline Tinggi mesin & $=87 \mathrm{~cm}$ \\
Diameter handle & $=1,5 \mathrm{~cm}$ \\
Panjang handle & $=8,5 \mathrm{~cm}$ \\
Ketebalan holding hole & $=1 \mathrm{~cm}$ \\
Diameter mesin rolling & $=46 \mathrm{~cm}$ \\
\hline
\end{tabular}
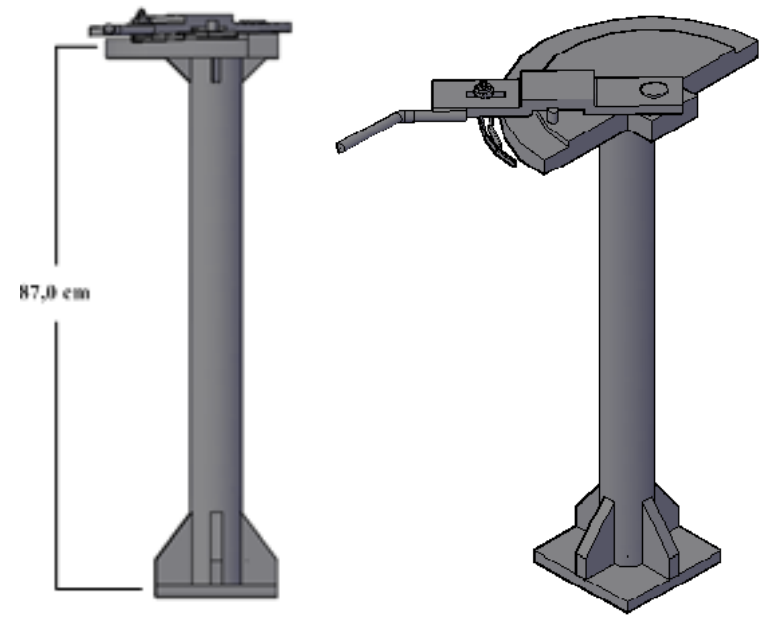

Gambar 2. Mesin rolling aktual
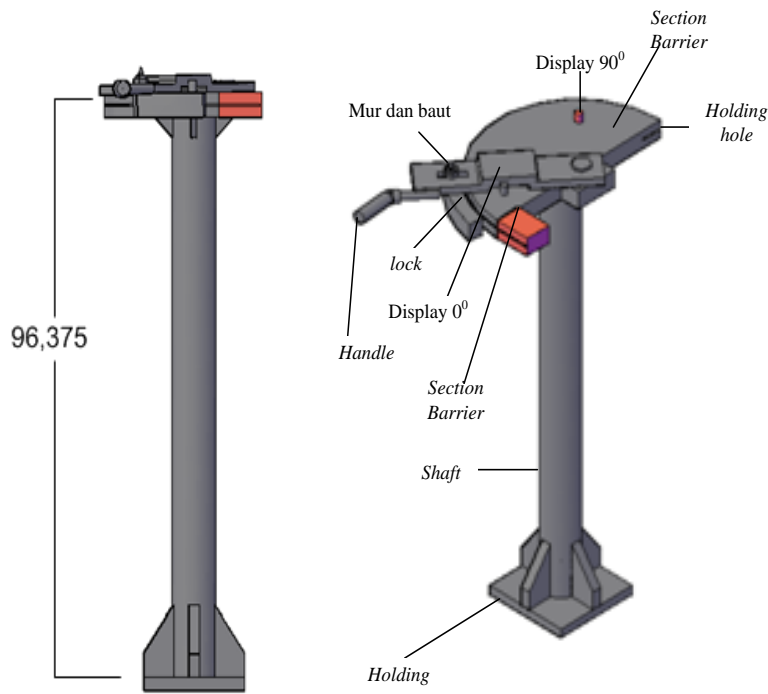

Gambar 3. Mesin rolling usulan 
Tabel 7. Spesifikasi mesin rolling usulan

Mesin rolling baru
Tinggi mesin $=96,375 \mathrm{~cm}$
Diameter handle $=4,987 \mathrm{~cm}$
Panjang handle $=10,233 \mathrm{~cm}$
Ketebalan holding hole $=0,5 \mathrm{~cm}$
Diameter mesin rolling $=46 \mathrm{~cm}$
Jangkauan terjauh handle $=65,825 \mathrm{~cm}$
Fungsi tambahan sebagai standard section barrier $=8,2 \mathrm{~cm}$
Display yang menunjukkan sudut $0^{0}$ dan $90^{\circ}$

Penjelasan modifikasi mesin rolling usulan adalah sebagai berikut:

Dimensi tinggi mesin rolling disesuaikan dengan ukuran antropometri operator berdasarkan pengolahan data sehingga operator tidak perlu membungkuk ketika bekerja. Diameter handle disesuaikan dengan dimensi tangan operator dan dilapisi dengan busa sehingga lebih nyaman. Ketebalan holding hole disesuaikan dengan ketebalan egrek dan posisinya diletakkan pada bagian tengah penampang mesin sehingga percikan api tidak mengenai operator. Jangkauan handle disesuaikan dengan jangkauan terjauh tangan operator. Membuat fungsi tambahan pada bagian ujung mesin yaitu section barrier sepanjang $8,2 \mathrm{~cm}$ sebagai patokan agar bagian ujung egrek yang tidak dibengkokkan tepat 8 cm sehingga tidak memerlukan proses pemeriksaan. Menambahkan display yang menunjukkan sudut $0^{0}$ dan $90^{\circ}$ sebagai patokan pada saat egrek dibengkokkan.

Alat bantu yang digunakan selama ini oleh pekerja juga masih jauh dari keadaan aman. Kekurangan alat bantu aktual pegangan egrek (Gambar 4): Pada saat mengangkat egrek yang telah dipanaskan, operator menggunakan tang karena gagang egrek yang sangat panas dan kemudian dimasukkan ke dalam air agar dingin sehingga operator dapat memegang gagangnya ketika akan dibengkokkan. Untuk menghilangkan beberapa kegiatan kerja yang tidak perlu, dan yang dapat menimbulkan bahaya, perlu dilakukan perancangan alat bantu yang ergonomis.

Untuk mengurangi kegiatan yang berbahaya dirancang suatu alat bantu yaitu, pegangan egrek, seperti terlihat pada Gambar 5.

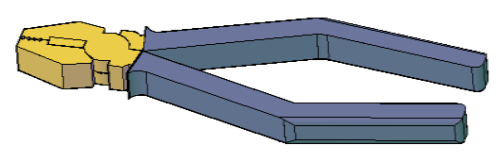

Gambar 4. Alat bantu aktual (tang)

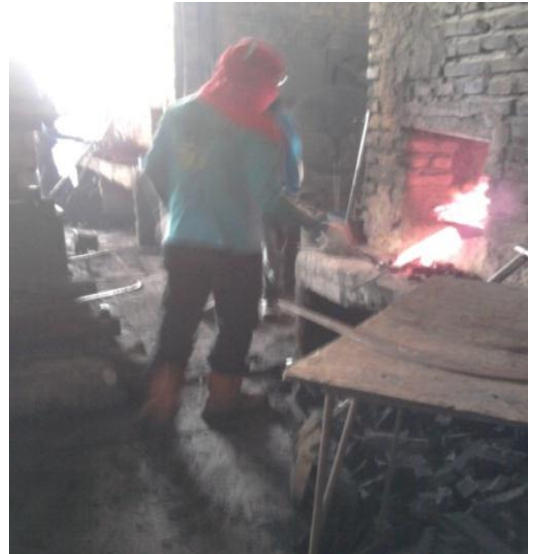

Gambar 5. Mengambil carbon steel yang sudah dipanaskan

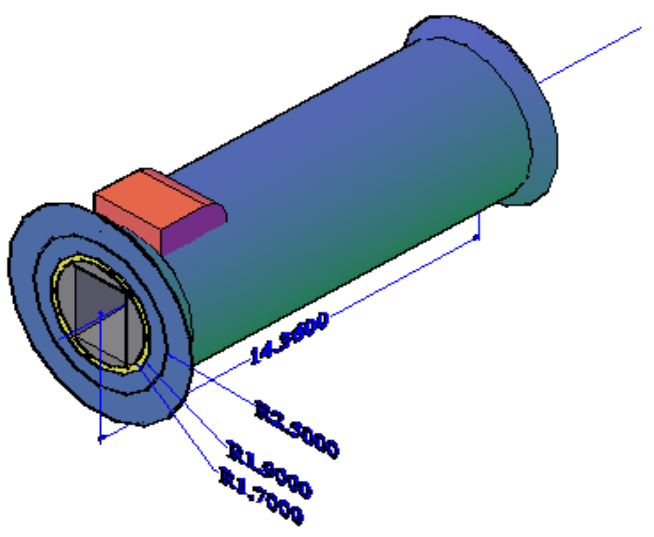

Gambar6. Alat bantu usulan pegangan egrek

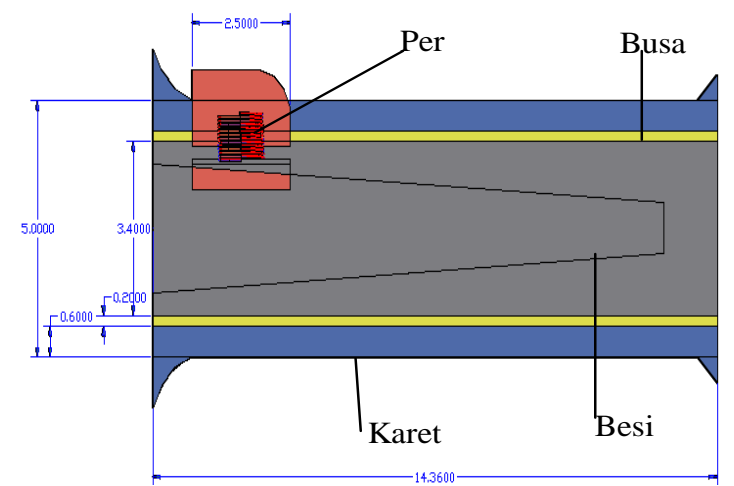

Gambar 7. Alat bantu usulan pegangan egrek potongan A-A

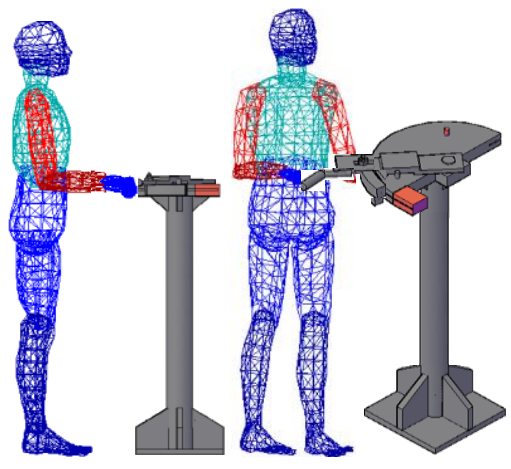

Gambar 8. Ilustrasi postur kerja baru 
Tabel 8. Perbandingan postur kerja aktual dan usulan

\begin{tabular}{lll}
\hline Postur aktual & Skor & Tindakan \\
\hline Proses pembengkokkan dengan & $58,52 \%$ & Tindakan \\
menarik tuas mesin rolling & & $\begin{array}{l}\text { dalam waktu } \\
\text { dekat }\end{array}$ \\
Postur baru & Skor & Tindakan \\
Proses pembengkokkan dengan & $48,29 \%$ & Perbaikan \\
menarik tuas mesin rolling & & waktu ke \\
& & depan \\
\hline
\end{tabular}

Penjelasan alat bantu usulan pegangan egrek: Alat bantu pegangan egrek yang dirancang disesuaikan dengan dimensi antropometri operator yaitu dengan ukuran mesin sebagai berikut. Panjang alat bantu: $14,36 \mathrm{~cm}$, Diameter: 4,987 cm dan Ukuran tombol = $2,546 \mathrm{~cm}$.

Lapisan dalam terbuat dari besi dengan diameter $3,4 \mathrm{~cm}$ dengan ruang berbentuk persegi yang disesuaikan dengan ukuran gagang egrek. Besi dilapisi dengan karet jenis vitton sebagai bahan anti panas. Pada lapisan bagian luar dilapisi dengan busa yang lembut sehingga nyaman pada saat menggunakannya. Diberikan penambahan tombol yang dilengkapi per untuk menjepit egrek pada saat diangkat. Proses pengangkatan egrek dilakukan setelah selesai pembentukan gagang egrek melalui proses pemanasan.

Pencelupan pada wadah yang berisi air untuk proses pendinginan gagang egrek yang telah terbentuk. Setelah diangkat egrek dibawa ke mesin rolling untuk dilakukan proses pembengkokkan.

Setelah dilakukan perancangan alat bantu kerja, maka dihasilkan penurunan besar gaya otot yang dikeluarkan operator pada proses pembengkokkan menjadi 1968,74 $\mathrm{N}$ dari 4170,51 N.

$W_{\text {badan }}=67 \mathrm{~kg}=656,6 \mathrm{~N}$;

$W_{0}=10,6 \mathrm{~kg}=103,88 \mathrm{~N} ; \sum F_{y}=0 ; \sum F_{x}=0 ; \sum M=0$

Adapun perhitungan selengkapnya adalah sebagai berikut.

Gaya otot pada spinalerector:

a. Telapak tangan

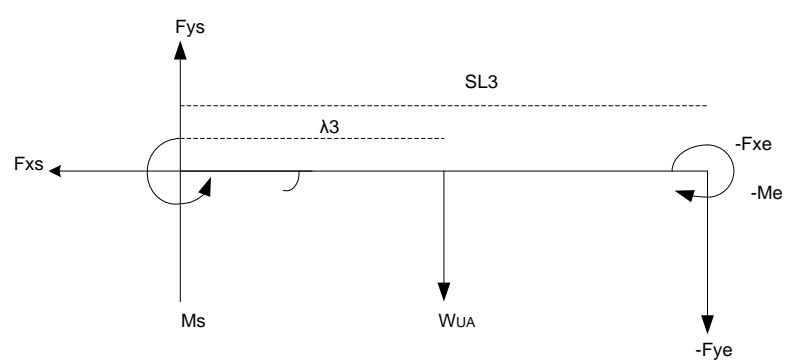

$S_{L 1}=0,17 \mathrm{~m} ; \theta=0^{0}$

$W_{H}=0,6 \% W_{\text {badan }}=3,9396 N$

$M_{w}=\left(0,5 W_{H}+W_{0}\right) S_{L 1} \cos \theta$

$=17,981 \mathrm{Nm}$ b. Lengan bawah

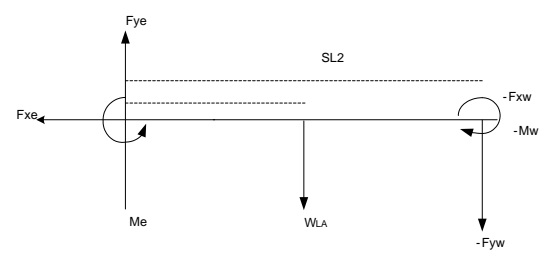

$S_{L 2}=0,26 \mathrm{~m} ; \lambda_{2}=43 \% ; \theta_{2}=0^{0}$

$W_{L A}=1,7 \% W_{\text {badan }}=11,16 \mathrm{~N}$

$F_{y e}=F_{y w}+W_{L A}=118,89 N$

$M_{e}=M_{w}+\left(W_{L A} \lambda_{2} S_{L 2} \cos \theta_{2}\right)+\left(F_{y w} S_{L 2} \cos \theta_{2}\right)$

$$
=49,219 \mathrm{Nm}
$$

c. Lengan atas

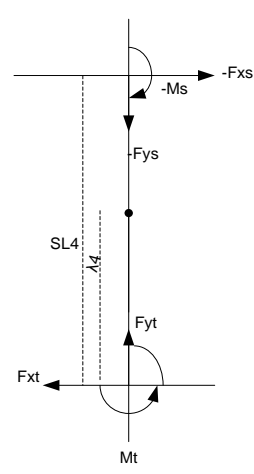

$S_{L 3}=0,24 \mathrm{~m} ; \lambda_{3}=43,6 \% ;$

$\theta_{3}=90^{\circ}$

$W_{U A}=2,8 \% W_{\text {badan }}=18,385 \mathrm{~N}$

$F_{y s}=F_{y w}+W_{U A}=137,365 \mathrm{~N}$

$M_{S}=M_{w}+\left(W_{U A} \lambda_{3} S_{L 3} \cos \theta_{3}\right)$

$+\left(F_{y e} S_{L 3} \cos \theta_{3}\right)$

$=49,219 \mathrm{Nm}$

d. Punggung

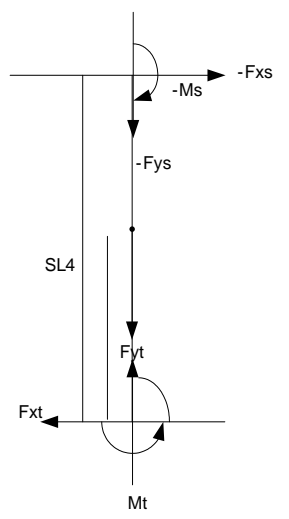

$S_{L 4}=0,56 \mathrm{~m} ; \lambda_{4}=67 \% ;$

×x $\theta_{4}=90^{\circ}$

$W_{T}=50 \% W_{\text {badan }}=328,3 \mathrm{~N}$

$F_{y t}=2 F_{y s}+W_{T}=603,03 N$

$M_{t}=2 M_{s}+\left(W_{T} \lambda_{4} S_{L 4} \cos \theta_{4}\right)$

$+\left(2 F_{y s} S_{L 4} \cos \theta_{4}\right)$

$=98,438 \mathrm{Nm}$

$P_{A}=\frac{1}{75}\left(10^{-4}\left[43-0,36\left(\theta_{H}+\theta_{T}\right)\right]\left(\frac{M_{L 5}}{S_{1}}\right)^{1,8}\right)$

$=0,1124$

$F_{A}=P_{A} \times A_{A}=0,1124 \times 465 \mathrm{~cm}^{2}=52,304 \mathrm{~cm}^{2}$

$F_{m} \mathrm{x} E=\frac{M_{L 5}}{S_{1}}-F_{A} D$ maka $F_{m}=1968,75 N$

$W_{\text {tot }}=W_{0}+2 W_{H}+2 W_{L A}+2 W_{U A}+W_{t}=393,27 N$

$F_{c}=W_{\text {tot }} \cos \theta_{4}-F_{A}+F_{m}=1968,74 N$

saat ini diperoleh $F_{c}<A L(1968,74<3500)$ dimana AL adalah ketetapan, maka gaya angkat dikategorikan aman.

Membuat adanya perancangan fasilitas kerja baru maka SOP proses pembengkokkan mengalami perubahan dan elemen kerja "periksa hasil pem- 
Tabel 9. Perbandingan penilaian biomekanika aktual dan baru

\begin{tabular}{lccccc}
\hline \multicolumn{1}{c}{ Elemen kegiatan aktual } & $\begin{array}{c}\text { Besar nilai } \\
\text { Fc }(\mathrm{N})\end{array}$ & \multirow{2}{*}{ Kategori } & Elemen kegiatan baru & $\begin{array}{c}\text { Besar nilai } \\
\text { Fc }(\mathrm{N})\end{array}$ & Kategori \\
\hline $\begin{array}{l}\text { Proses pembengkokkan dengan } \\
\text { menarik tuas mesin rolling }\end{array}$ & 4170,51 & Perlu hati-hati & $\begin{array}{l}\text { Proses pembengkokkan dengan } \\
\text { menarik tuas mesin rolling }\end{array}$ & 1968,74 & Aman \\
\hline
\end{tabular}

Tabel 10. Perbandingan uraian kerja aktual dan baru

\begin{tabular}{|c|c|c|c|}
\hline Kode & Uraian kerja aktual & Kode & Uraian kerja baru \\
\hline 1.1. & $\begin{array}{l}\text { Letakkan plat hasil dari proses sebelumnya di dekat } \\
\text { tungku pembakaran. }\end{array}$ & 1.1. & $\begin{array}{l}\text { Letakkan plat hasil dari proses sebelumnya di dekat } \\
\text { tungku pembakaran. }\end{array}$ \\
\hline 2.1. & $\begin{array}{l}\text { Letakkan ujung plat pada tungku pembakaran untuk } \\
\text { membentuk gagang egrek }\end{array}$ & 2.1. & $\begin{array}{l}\text { Letakkan ujung plat pada tungku pembakaran } \\
\text { untuk membentuk gagang egrek }\end{array}$ \\
\hline 2.2. & $\begin{array}{l}\text { Panaskan ujung plat yang telah terbentuk selama } 5 \\
\text { menit. }\end{array}$ & 2.2. & Panaskan egrek selama 5 menit. \\
\hline 3.1. & $\begin{array}{l}\text { Masukkan gagang egrek ke dalam wadah berisi air } \\
\text { dan langsung diangkat. }\end{array}$ & 3.1. & $\begin{array}{l}\text { Masukkan gagang egrek ke dalam wadah berisi air } \\
\text { dan langsung diangkat. }\end{array}$ \\
\hline 4.1. & an kunci egrek pada mesin rolling & 4.1 . & Angkat dan letakkan egrek pada mesin rolling \\
\hline 4.2. & htuk pembent & 4.2 . & esin rolling \\
\hline 4.3. & pembengkokkan & - & - \\
\hline & Letakkan egrek pada mesin hammer & 5.1. & n hammer \\
\hline 5.2. & Lakukan proses pukul rata & 5.2. & Lakukan proses pukul rata \\
\hline
\end{tabular}

bengkokkan" ditiadakan karena telah dirancang fungsi tambahan, yaitu standard Section barrier dan display yang menunjukkan sudut $0^{\circ}$ dan $90^{\circ}$. Perbandingan uraian kerja aktual dan baru dapat dilihat pada Tabel 10 .

Adanya perancangan fasilitas kerja yang baru, operator masih harus menyesuaikan diri (memerlukan proses pembelajaran) dalam proses penggunaan mesin tersebut sehingga pada tahap awal penggunaan mesin, operator masih memiliki kemungkinan untuk melakukan error maka timbul EPCs yang baru sedangkan factor EPCs yang lama dapat dihilangkan. Melalui perancangan fasilitas kerja baru, maka faktor EPCs yang muncul adalah dibutuhkan teknik (cara) yang berbeda dari biasanya dalam melakukan pekerjaan dengan nilai maximum effect 6 dan APOE 0,6. Nilai Assessed Effect adalah ((Max.Effect-1) xAPOE)+1) sehingga diperoleh nilai Assessed Effect $=4$. Probabilitas human error setelah perancangan mengalami penurunan menjadi 0,1590. Penurunan human error terjadi karena faktor penyebab error (EPCs) yang sebelumnya dapat dihindarkan.

\section{Simpulan}

Hasil pengolahan data dan analisa pembahasan memberikan beberapa kesimpulan sebagai berikut, Keluhan musculoskeletal yang dialami operator berdasarkan kuesioner SNQ dan Plibel terdapat pada anggota tubuh bagian atas yaitu leher, bahu, lengan, tangan, punggung, dan pinggang. Keluhan ini disebabkan karena dimensi mesin rolling yang tidak sesuai dengan antropometri operator dan gaya otot yang dikeluarkan operator cukup besar serta kegiatan yang dilakukan bersifat repetitif. Hasil penilaian postur kerja menunjukkan bahwa elemen kegiatan pembengkokkan membutuhkan tindakan dalam waktu dekat dengan skor sebesar 58,52\% dan berdasarkan perhitungan gaya otot pada segmen tubuh telapak tangan, lengan bawah, lengan atas, dan punggung elemen kegiatan pembengkokkan termasuk ke dalam kategori perlu hati-hati dengan nilai gaya kompresi pada L5/S1 $\left(\mathrm{F}_{\mathrm{c}}\right)$ sebesar 4170,5 N. Pada proses pembengkokkan. Total human error aktual yang terjadi adalah 0,5978\%. Untuk mengurangi hasil penilaian postur kerja, biomekanika dan human error maka dilakukan suatu perancangan mesin rolling yang ergonomis dan perancangan alat bantu pegangan yang disesuaikan dengan antropometri operator. Setelah melakukan perancangan mesin rolling yang ergonomis dan alat bantu pegangan, terdapat elemen kegiatan yang hilang yaitu proses pemeriksaan. Setelah melakukan penilaian kembali setelah perancangan, postur tubuh operator menjadi lebih aman dan skor tindakannya sebesar 48,29\% dan berdasarkan perhitungan biomekanika, besar gaya kompresi pada L5/S1 (Fc) menjadi 1968,74 $\mathrm{N}$ dan termasuk dalam kategori aman. Demikian juga dengan probabilitas human error mengalami penurunan menjadi 0,1590\%.

\section{Daftar Pustaka}

1. Aghili, Mir M. M., Asilian, H., and Poursafa, P., Evaluation of Muskuloskeletal Disorder in Sewing Machine Operators of a Shoe Manufacturing Factory in Iran, International Journal of Industrial Ergonomics, 62(3), 2012, pp. 20-25.

2. Akash, K. B., and Kshyudda. S. C., Medical Human Factor Engineering and Workspace 
Design, Journal of Interscience Management Review (IMR), 2 (2), 2012, pp.21-25.

3. Dhillon, B. S., Human Reliability: With Human Factors, Pergamon Press, Exeter, UK, 1987.

4. Fabio, D. F., Antonella, P., Armando, C., and Antonio, R., Human Reliability Analysis: A Review of the State of the Art, International Journal of Research in Management and Technology (IJRMT), 2(1), 2012, pp.35-41.

5. Hendra and Suwandi, R., Risiko Ergonomi dan Keluhan Musculoskeletal Disorde (MSDs) pada Pekerja Panen Kelapa Sawit, Prosiding Seminar Nasional Ergonomi IX, Semarang, 1718 November 2009.

6. Humantech, Humantech Applied Ergonomics Training Manual, 2nd.ed., Berkeley, Australia, 1995.

7. Lyons, M. A.,Sally, B., Woloshynowych, M., and Vincent, C., Human Reliability Analysis in Healthcare: A Review of Techniques, International Journal of Risk and Safety in Medicine IOS Press, 16, 2004, pp. 223-237.
8. Meister, D., Behavioral Foundations of System Development, John Wiley \& Sons, New York, 1976.

9. Nurmianto, E., Ergonomi Konsep Dasar dan Aplikasinya, Guna Widya, Jakarta, 1996.

10. Pheasant, S., Ergonomics, Work and Health, Aspen Publishers Inc, USA, 1991.

11. Reinach, S. J., Fadden, S., Gamst, F. C., and Acton, S. A.,The Use of HEART to Assess the Risk of Remote Control Locomotive Operations: A Tale of Two Cities, Proceedings of the Human Factors and Ergonomics Society 51 ${ }^{\text {st }}$ Annual Meeting-2007, pp. 1411-1415.

12. Stanton, N., Handbook of Human Factors and Ergonomics, CRC Press LLC, United States of America, 2005.

13. Susetyo, J., Isna, O. T., and Hastiko, H. I., Prevalensi Keluhan Subyektif atau Kelelahan karena Sikap Kerja yang Tidak Ergonomis pada Pengrajin Perak, Jurnal Teknologi, 1(2), 2008, pp. 141-149. 